Vol. 16, $n^{\circ} 1 \mid 2012$

Varia

\title{
Thurston (Robert W.), Lynching : American Mob Murder in Global Perspective
}

Farnham, Surrey, and Burlington, VT, Ashgate, 2011, 427 p., ISBN

978-1-4094-0908-3 (HB).

Neil A. Wynn

\section{OpenEdition}

\section{Journals}

Édition électronique

URL : https://journals.openedition.org/chs/1338

DOI : $10.4000 /$ chs. 1338

ISSN : 1663-4837

Éditeur

Librairie Droz

Édition imprimée

Date de publication : 1 mai 2012

Pagination : 129-131

ISBN : 978-2-600-01594-3

ISSN : 1422-0857

Référence électronique

Neil A. Wynn, «Thurston (Robert W.), Lynching : American Mob Murder in Global Perspective », Crime, Histoire \& Sociétés / Crime, History \& Societies [En ligne], Vol. 16, $n^{\circ} 1$ | 2012, mis en ligne le 12 mars 2013, consulté le 22 mars 2022. URL : http://journals.openedition.org/chs/1338 ; DOI : https://doi.org/ $10.4000 /$ chs. 1338

Ce document a été généré automatiquement le 22 mars 2022.

(C) Droz 


\section{Thurston (Robert W.), Lynching: American Mob Murder in Global Perspective}

Farnham, Surrey, and Burlington, VT, Ashgate, 2011, 427 p., ISBN

978-1-4094-0908-3 (HB).

Neil A. Wynn

\section{RÉFÉRENCE}

Thurston (Robert W.), Lynching : American Mob Murder in Global Perspective, Farnham, Surrey, and Burlington, VT, Ashgate, 2011, 427 p., ISBN 978-1-4094-0908-3 (HB).

1 Lynching is generally regarded as an American phenomenon and more particularly it is associated with the American South and the subjugation of the African American population in the former Confederate states. However, while the greatest percentage of lynchings after 1880 did take place in the South and with black victims, this was not always the case. The history of lynching in the USA offers a unique insight into the development of attitudes towards crime and punishment in American society since the time of the War of Independence. Even within the South, racial lynchings varied in number, form, and degrees of violence - from simple hangings in secluded woods to torture and burning at the stake before huge audiences. Robert Thurston sets out to examine the complexities of lynching in order to move away from simplistic onedimensional stereotypes of it as a means used by outraged or anxious whites simply as a "way of keeping blacks down". His title suggests that the subject will be located within a broad context, and given that his previous work was on Life and Terror in Stalin's Russia, the reader might anticipate that American practices would be compared and contrasted in some detail with events elsewhere. Indeed, early on Thurston does refer to mob murder in other countries (ranging from peasant justice in Russia, "necklacing" in Africa, and collective murders in India, Bolivia and Guatamala) to offer 
"important perspectives on issues of race and class in US violence". However, this is never done in a consistent way: while the fleeting references to other countries provide some useful points of comparison these are often rather tenuous or superficial. The main focus throughout is on events in the USA and somewhat surprisingly, mainly on racial lynching in the South in the late-nineteenth century.

2 Lynching only became a predominantly racial phenomenon in America from the 1880s, while earlier the majority of the victims of extra-legal mob justice were white. The origins of the term lay in the upheavals of the War of Independence when former colonists established "courts" under the separate guidance of Charles Lynch and William Lynch (no relative), both in Virginia. Early lynchings were not necessarily fatal - they could involve tarring-and-feathering or other public humiliation. Later, lynching became associated with the West, either as a fatal rough-and-ready punishment for cattle rustling or horse stealing, or as retribution for other crimes which were not handled by the courts as local communities wished. Indeed, as Thurston points out, but does not really develop, the classic defence of lynching appeared in Owen Wister's novel The Virginian in 1906 when Judge Henry differentiated between lynching rustlers in the West and the murder of African Americans in the South. Lynching also occurred in other frontier towns ranging from San Francisco in the 1850s through to the mining camps of Colorado in the 1890s. The victims could be thieves, murderers, labour activists, or simply those of the wrong ethnic, religious or political persuasion. Little of this emerges in Thurston's study and one major omission from any discussion of the South is the murder in New Orleans in 1890 of 11 Italians ("Sicilians") accused of being members of the Mafia, an event that caused an international diplomatic incident.

Given the variety of lynchings, finding a simple explanation to connect them all is virtually impossible. As Thurston says, there really is an absence of pattern with enormous differences between often similar states such as Mississippi and South Carolina, and some areas of the South that saw no lynchings at all. "Taking the law into their own hands" seemed to occur in periods of crisis (political, social, and economic) or simply when courts failed to carry out the will of the general public. Using various literary references over a number of broad chapters, in which lynching as such disappears from the reader's view, Thurston argues rather unconvincingly that the changing incidence of racial lynching reflected shifting images and attitudes on race, manliness, sexuality and femininity: "The profound and growing changes before World War I surrounding issues of race, sex, and civilization help to explain the decline of lynching after 1892." (191). The decline, later referred to as quick, was from a high of 161 in 1892 to an annual average of 104 over the next decade. Lynching of African Americans continued in double figures near to 100 annually through until the 1920 s. Although he is at pains to point out that accusations of rape were not as significant as believed as a cause of racial lynching in the South, Thurston spends a great deal of time looking at changing attitudes towards race and sexuality and is given to sweeping (and contradictory) statements such as the claim that 'Whites' anxieties over interracial liaisons peaked around the world from about 1900 until 1930" (203).

The book opens and closes with the horrific lynching in Georgia in 1918 of 11 African Americans including a woman and her unborn child who were burnt alive. While this incident might point to the continuation of racial violence, Thurston focussed on the response of respectable white southerners and particularly Governor Hugh Manson Dorsey to suggest that white attitudes were changing. Dorsey, in 1913 the successful 
prosecutor of Leo Frank - a Jew sentenced to death for murdering a 13-year-old girl who was then lynched when his sentence was commuted - criticised the lynchings of 1918 and subsequently held a conference to mobilise anti-lynching feeling. For Thurston, Dorsey's position revealed the influences of the "long, global discussion" on race and his actions helped "push lynching farther to the margins of southern life" (403). Ultimately, the book argues that there was not one South, but many, not one southerner, but many, and that to understand lynching needs not just one narrative but many. Perhaps in attempting too much, the author lost sight of these narratives and sadly, their global significance.

\section{AUTEURS}

\section{NEIL A. WYNN}

University of Gloucestershire nwynn@glos.ac.uk 